This is an Accepted Manuscript of an article to be

published by Taylor \& Francis in Business History.

\title{
WHITE-COLLAR CRIME AND THE LAW IN NINETEENTH-CENTURY BRITAIN
}

Dr James Taylor, Lancaster University

\begin{abstract}
Rapid commercial development in Britain by 1800 inspired legislation rendering 'white-collar' crimes such as forgery, embezzlement, and obtaining money by false pretences criminally punishable. However, it was unclear how far this legislation applied to the managers and directors of companies, with the result that in practice, they could only be reached by actions in the civil courts. As the corporate economy grew, whether the criminal law should be extended to company managements became a pressing issue. This article explores these debates and examines the complex and tentative process of legal change which, though contested and controversial, resulted by 1900 in the effective criminalisation of a host of 'white-collar' offences.
\end{abstract}

Keywords: corporate fraud; white-collar crime; criminal law; law enforcement; regulation

Though the subject of 'white-collar' crime has spawned a huge literature in a number of disciplines since Edwin Sutherland's ground-breaking work, historical understanding of such crimes has undoubtedly lagged. ${ }^{1}$ In a British context, though the topic of crime and society in the eighteenth and nineteenth centuries has been the subject of much work since the 1970s, the bulk of this focused on the relationship between law and the working classes, and 
essentially viewed the law as an instrument of class oppression. ${ }^{2}$ It was not until 1992 that the history of white-collar crime was the subject of a monograph, George Robb's White-Collar Crime in Modern England. ${ }^{3}$ Though Robb's work did not immediately spark a significant upswing in historical research on the topic, since the late 1990s scholars have begun to research the histories of forgery and embezzlement. ${ }^{4}$ Frauds associated with the corporate economy, particularly misappropriation and misrepresentation by management, have also attracted more attention, and are the focus of this article.

Historians have tended to argue that it took Parliament and the courts a very long time to tackle these kinds of frauds, and that effective responses really only came after Labour's election victory in 1945. Two principal explanations for this are advanced: first, the ideology of laissez faire which allegedly shaped economic policies until it began to be challenged from the late nineteenth century by more collectivist approaches, and second, the class bias of the criminal justice system: the net of the law was designed to catch the small fry, but to let the big fish - such as powerful and well-connected company directors - go free. ${ }^{5}$ This article argues that these interpretations are misleading: they misrepresent the reasons for inaction in the earlier nineteenth century, and underestimate the extent to which obstacles to criminalisation were overcome in the later part of the century.

As such, it is part of a recent trend in scholarship re-evaluating legal and political responses to fraud in the nineteenth century. As early as 2000, Sarah Wilson identified a new 'determination to respond' to frauds by company directors in the $1850 \mathrm{~s}$, with the courtroom providing 'an important location for discussions of respectability' in which the parameters of criminality were renegotiated. ${ }^{6}$ These insights were followed by several articles exploring the process of criminalisation around mid-century. ${ }^{7}$ This work has been developed recently in longer studies exploring Victorian legal innovations in greater depth, which argue that the 
process of defining and tackling white-collar crime was very much a response to the growth of the corporate economy in the nineteenth century. ${ }^{8}$

By giving a long-run perspective on responses to corporate fraud, this article seeks to provide essential historical context for contemporary debates. Studies which assume that white-collar crime only began to be taken seriously in the later twentieth century - only after Sutherland had named it - give a very limited view of how modern societies have grappled with the problem of fraud. Taking into account the earlier history sheds new light on several areas of current interest among scholars of white-collar crime, ranging from the lack of criminal prosecutions following the 2008 financial collapse, to the effectiveness and limitations of extra-legal forms of punishment. ${ }^{9}$

The article is divided into three sections. The first section explores the primary obstacles to the criminal prosecution of fraud in a period which saw the rapid development of the corporate economy. The second section details how these obstacles weakened around mid-century, paving the way for the definition and criminalisation of company fraud offences in statute law, but not for their consistent enforcement. The final section focuses on greater state involvement in prosecution, leading to the construction by the end of the Victorian era of legal mechanisms to tackle fraudulent offences by company executives. These mechanisms were far from perfect, but they enabled the criminal law to begin to reach into Britain's boardrooms in an entirely unprecedented way.

\section{Obstacles to the criminal prosecution of company fraud}

Perhaps surprisingly for those who have only studied white-collar criminality in modern contexts, the eighteenth-century state was in fact very active in this sphere. The so-called 'Bloody Code' - the raft of capital statutes passed in the long eighteenth century - was 
particularly focused on crimes against property. ${ }^{10}$ Though much of this legislation was designed to protect property from the depredations of the poor, it also encompassed what would much later come to be seen as 'white-collar' crimes, among them forgery. In 1697, Bank of England paper was protected by a capital statute, a penalty which was subsequently extended piecemeal to other corporations, until 1729 when a general act was passed, covering the range of paper instruments on which the credit economy depended. Parliament also targeted other white-collar crimes. An act of 1757 criminalised obtaining goods or money by false pretences with intent to defraud, and while this was not a capital statute, the maximum penalty was nevertheless stern: transportation for seven years. ${ }^{11}$ Various acts against embezzlement were passed between 1742 and 1767, culminating in a statute of 1799 which applied more generally. Again, the maximum penalty was severe: transportation for 14 years. ${ }^{12}$ Finally, the common law of conspiracy could be used to tackle any offence not explicitly covered by legislation.

Clearly, this was not a society which blanched from using the criminal law to regulate commercial behaviour, or from applying the terror of the law to well-to-do miscreants. Forgery trials were sensational affairs, and in the event of a conviction, the death penalty was deployed with regularity: indeed, forgers had replaced highwaymen as the 'great crooks of the latter part of the eighteenth century'. ${ }^{13}$ The difficulty arose when applying the laws against white-collar crime to actors in joint-stock companies. These were often, by the standards of the day, large, complex organisations made up of a variety of constituents, including directors, managers, shareholders, and employees. It was therefore much harder to pinpoint wrongdoing: those accused could play pass-the-parcel with responsibility, denying knowledge and seeking to pin the blame elsewhere. The novelty and intricacy of transactions involved in the joint-stock economy also militated against punishment. Offences such as manipulating the market price of shares - one of the 'crimes' of the directors of the South Sea 
Company during the bubble of 1720 - were widely condemned when exposed, but could such acts really form the basis of a criminal prosecution ${ }^{14}$

Moreover, proving fraudulent intent - the mens rea or guilty mind - was essential for a successful prosecution in the criminal courts. But demonstrating this in the case of a jointstock company could be particularly difficult. For example, directors accused of deceiving shareholders by concealing a firm's parlous financial condition through issuing false balance sheets could claim that they were doing so with 'honest' intentions - to enable the company to survive troubled times and return to profitability. If telling the truth would trigger a panic and destroy the company, was this really in the best interests of shareholders? ${ }^{15}$ Furthermore, it would be wrong to assume that there was one static and universal code of commercial morality for the whole country. What was condemned as sharp practice in one city might be accepted as normal behaviour in another. Such conflicting codes were uncovered during a parliamentary investigation into a series of joint-stock bank failures in the mid-1830s. One of the reasons why one Manchester firm, the Northern and Central Bank, had suspended payment was because of a policy of discounting high-risk bills for its customers without careful inspection by the directors. But a variety of witnesses before the parliamentary committee insisted that this was not rogue practice, but simply the Manchester way of doing business. ${ }^{16}$ In such a context, enforcing a single code of morality by means of the criminal law would seem highly objectionable.

The moral waters were further muddied by popular attitudes to shareholders, widely seen as the principal victims of directorial fraud. Shareholders in companies, whether incorporated by the state or unincorporated, were typically understood to be more like partners than rentier investors. As partners, they bore some responsibility to regulate their executives. Company constitutions, often meticulously detailed documents, endowed shareholders with various and wide-ranging rights, which meant that if their executives 
behaved badly, shareholders could set up committees of investigation, identify wrongdoing, and if necessary, remove officials from office. Misbehaviour could not easily be concealed, because shareholders typically had the right to examine account books and other documents, while the annual audit was often conducted at the general meeting. ${ }^{17}$ This was the logic behind the unlimited liability regime which was the norm until 1855: because shareholders stood to lose everything, they had a direct financial incentive to perform their regulatory role. $^{18}$

This was the theory, but it often seemed that shareholders behaved very differently in practice, especially during periods of speculative excitement. ${ }^{19}$ Eager to make quick profits, they invested their money without due caution, allowing executives free rein to behave as they wished. If this led to sharp practice, investors bore the ultimate responsibility. Were the law to step in to bail them out, the principles underpinning corporate governance would be weakened, and the result would be even rasher speculation in the future. The classic articulation of this point of view came when Prime Minister William Gladstone defended his government's decision not to order the prosecution of the directors of Overend and Gurney, a large discount bank which had failed in 1866 triggering a general panic. Such a prosecution, argued Gladstone, would have a terrible effect 'on the future prudence and self-restraint of a generation too greedy of money and too ready to adopt one of the most doubtful means of making money — that of placing their investments in concerns of which they know nothing at all, with the view of making large and easy gains, of reaping the fruits of industry without its toil. ${ }^{20}$ In other words, buying a share incurred responsibilities as well as the right to collect dividends.

What strengthened this prejudice against speculators was the belief that the victims were wealthy and were driven to speculation by greed rather than necessity. Such views proliferated in the aftermath of the collapse of the 'railway mania' of the mid-1840s in which 
many middle-class shareholders suffered huge losses. ${ }^{21}$ For example, in a leader entitled 'Mammon-Worship', Lloyd's Weekly Newspaper argued that '[h]ad railway proprietors been satisfied with a legitimate profit, they would not have sustained that damage to their private interests of which they now complain. ${ }^{22}$ When victims were less affluent, and where investment rather than speculation was the goal, the moral judgements were recalibrated. ${ }^{23}$ The class dimension is very apparent when considering the firmer response to frauds in savings banks where the victims were generally working-class. Depositors in such banks did not possess the same regulatory powers as shareholders in joint-stock companies, and were thought to be less competent to hold their social superiors to account. Commentators were therefore far less likely to blame the victim: indeed, the press was disgusted at 'the shocking plunder of the poor and industrious classes' involved in such cases. ${ }^{24}$ Savings bank fraud was thus considered a more appropriate site for the exercise of the criminal law, with several savings bank officials successfully prosecuted in the criminal courts between the 1840s and the 1860 s. $^{25}$

Company executives would be regulated from within by shareholders, but they would also be regulated from without by wider society. In cases when bad behaviour was exposed by shareholder committees of investigation, the next step would be general publicity. Press reporters typically attended company general meetings, and accounts of such events, alongside other local meetings, represented an important ingredient of the nineteenth-century newspaper. Though executives often tried to bar reporters from attending general meetings at times of internal crisis or controversy, such attempts were often overruled by shareholders, or were otherwise thwarted by shareholders sharing notes with reporters immediately after a meeting. ${ }^{26}$ In particularly bad cases, such reports would be accompanied by editorial comment drawing attention to boardroom corruption. For example, when shareholders in the Arigna Iron and Coal Mining Company discovered in 1825 that their directors had made a 
secret profit of $£ 15,000$ on the purchase of the company’s mines, detailed reports of the general meeting appeared in the next day's newspapers, together with editorial judgements. Among the most outspoken was the Morning Chronicle, which was appalled by what was 'esteemed correct and honourable' in the City. ${ }^{27}$ Though they never faced criminal prosecution, several key figures in the company, some of them Members of Parliament, suffered permanently compromised reputations. ${ }^{28}$ So, executives could not act with impunity: directors who did not live up to honest norms of behaviour would be purged from their boards, vilified in the press, and hounded from polite society. In a culture in which trust in business rested on a reputation for honesty, such extra-legal sanctions could be potent. ${ }^{29}$

Another obstacle to the criminalisation of fraud was the system of private prosecution in England and Wales. Most crimes were regarded as private matters, and it was therefore the responsibility of injured parties to prosecute. ${ }^{30}$ This did not mean that public prosecutions never happened - both the Attorney General and the Treasury Solicitor could step in to prosecute - but they very rarely did so in cases of company fraud. ${ }^{31}$ Scotland did have a public prosecutor in the Lord Advocate, but for much of the century this official did not have any track record of prosecuting cases of company fraud. ${ }^{32}$ It was easy to conceptualise frauds as private rather than public offences: the corporate economy in the early nineteenth century was relatively small, which meant that the effects of fraud were usually contained. The main victims were usually the shareholders who, as discussed above, were widely viewed as authors of their own misfortune. Moreover, getting involved in such prosecutions did not suit a state which after 1815 was pursuing a policy of retrenchment, attempting to place itself above sectional interests and to reduce burdens on the taxpayer in order to defend itself from accusations of 'Old Corruption'. ${ }^{33}$ Left to private initiative, company frauds were therefore rarely prosecuted: the victims of fraud, having just lost their money - perhaps everything they owned under the regime of unlimited liability - were usually ill-equipped to organise and 
finance a private prosecution. If they did resort to the law, it would more likely be the civil law which, if successful - and provided the defendants possessed sufficient assets - promised financial recompense. ${ }^{34}$

\section{Criminalising company fraud}

The force of these obstacles to the criminalisation of white-collar crime was significantly eroded in the second half of the century. A key catalyst for change was the newspaper press, although the role of the media is often seen very differently. Scholars of white-collar crime beginning with Sutherland have accused the media of downplaying the extent and significance of white-collar frauds, and focusing instead on street crimes. As 'large capitalistic enterprises' run by people with 'the same standards as the persons who manage other corporations', and heavily dependent on the advertising revenue provided by corporations, they have no incentive to be critical 'of business practices in general or of particular corporations'. ${ }^{35}$ More recently, scholars have continued to identify an 'ideological one-sidedness' in the mass media: their unremitting focus on proletarian crimes means that corporate crime is 'rendered invisible'. ${ }^{36}$ Others see the media's 'narrow definitions of crime' as the result of 'pandering to public tastes for drama and immediacy over complexity': in other words, white-collar crime is not as 'newsworthy' as more violent crimes. ${ }^{37}$ Yet there are dissenting voices, among them criminologist Michael Levi, who argues that basic empirical analysis refutes these theories. Any newspaper reader can find 'ample daily evidence' that crime is ' $n o t$ produced solely by the working and unemployed classes' ${ }^{38}$ Observing that 'it is mistaken to view "the media" as a coherent "institution", he argues that media coverage is not simply determined by its ownership by 'big business' 39 
Though Levi suggests that Sutherland may have been correct about the media ignoring white-collar crime at the time he wrote, ${ }^{40}$ Levi's point actually holds when examining nineteenth-century press coverage of frauds. Far from rendering corporate crime invisible, Victorian newspapers and periodicals were pivotal in the creation of white-collar scandals, even though they were already themselves substantial enterprises heavily dependent on advertising revenue. ${ }^{41}$ They were central, for example, in destroying the reputation of leading railway entrepreneur George Hudson after the collapse of the 'railway mania' in the mid-1840s. When committees of investigation appointed by shareholders identified a series of misdemeanours ranging from misappropriation of company funds to falsification of balance sheets, the press was quick to denounce Hudson. 'Corruption upon such a large scale as he has been charged with is unknown in this country since the South Sea Bubble,' claimed the Observer with more than a hint of hyperbole. ${ }^{42}$ The fact that modern assessments of Hudson's business practices have been somewhat more sympathetic suggests that the Victorian press could hardly be accused of downplaying the importance of corporate fraud. ${ }^{43}$

Though media censure did not lead to Hudson's prosecution in the criminal courts, the press was instrumental in impelling the state to act ten years later. ${ }^{44}$ A series of bank collapses in the mid-1850s was seized upon by the press to create a powerful scandal. The failure in September 1856 of the third institution in this sequence, the Royal British Bank, after its management had lost large amounts of money in mining speculations, and had made large unsecured loans to board members, triggered withering editorials condemning the inadequacy of the criminal law. ${ }^{45}$ The morality became even more clear-cut for the press as further revelations emerged during the bank's winding-up in the Court of Bankruptcy. Newspapers described the manager and directors as a gang of 'swindlers and pickpockets', 'delinquents', 'charlatans', 'knaves', and 'thieves'. ${ }^{46}$ Making matters even worse, a fourth bank, the London and Eastern Banking Corporation, failed during these proceedings. The 
press began baying for retribution, demanding that the letter of the law be 'strained to the utmost' to enable a prosecution, placing pressure on Lord Palmerston's Whig administration to act. ${ }^{47}$ Though the Attorney General, Sir Richard Bethell, sharply told the House of Commons that he would not 'be dictated to by a newspaper', he took the extraordinary step of launching a prosecution under the law of conspiracy, a measure it is highly unlikely that he would have taken without media coercion. ${ }^{48}$

The existing law was indeed stretched to the limit to secure a conviction, with six of the seven defendants found guilty under the law of conspiracy, and given sentences ranging from three to twelve months. ${ }^{49}$ The judge, Lord Chief Justice Campbell, then had to use all of his powers of persuasion to ensure that his fellow judges rejected an appeal by the defendants' lawyers. ${ }^{50}$ The fact that one of the six was subsequently granted a free pardon and three others were released early hints at the unease with which the conviction was regarded in political and legal circles, a product of the inadequacy of the law of conspiracy to deal with these kinds of offences. ${ }^{51}$ But this problem was tackled by the Punishment of Frauds Act, 1857, the Palmerston government's other response to the banking scandals of the mid-1850s.

The act, which passed Parliament with little debate, defined and punished three main offences. The first were crimes of larceny and embezzlement. It was now a misdemeanour for any 'Director, Public Officer, or Manager' of a company to 'fraudulently take or apply, for his own use, any of the money or other property' of the company (larceny) or to receive 'any of the money or other property' of the company for anything other than payment of a just debt, and 'with intent to defraud' omit to record this in the company's books (embezzlement). The second targeted the falsification of company books: management could not 'with intent to defraud, destroy alter, mutilate, or falsify any of the books, papers, writings, or securities' of the company, or 'make or concur in the making of any false entry, or any material 
omission in any book of account or other document'. The third addressed the dissemination of false statements: no director or officer could 'make, circulate, or publish, or concur in making, circulating, or publishing, any written statement or account which he shall know to be false in any material particular, with intent to deceive or defraud' any shareholder or creditor, or with intent to induce anyone to become a shareholder or creditor. ${ }^{52}$

The act's intent was clear: the criminal law was to apply not only to subordinates, but to directors and managers. The law was to cover not only crimes of misappropriation but also misrepresentation, sometimes considered less reprehensible than embezzlement, but often the means by which frauds could be concealed for long periods. And the penalty for these crimes was to be severe. The new punishment of penal servitude, introduced in 1853 as a replacement for transportation and intended to be particularly harsh, was applied. ${ }^{53}$ Although the maximum sentence was reduced from seven years to three while the bill was going through Parliament, this was subsequently increased back to seven by the Larceny Act of $1861 .^{54} \mathrm{~A}$ banking scandal had resulted in the transformation of the criminal law relating to the corporate economy as a whole: for the first time, company frauds were defined and punished in the statute books.

Good though the press was at creating a scandal, it could not sustain it indefinitely. While further cases of fraudulent practice in the banking sector emerged when the commercial crisis struck at the end of 1857 , these did not trigger further state prosecutions. After the Western Bank of Scotland closed its doors in November 1857, prompting a run on the other Scottish banks, it transpired that it had made large risky loans, falsified accounts, and declared substantial dividends out of capital. But now ministers felt more able to resist calls for prosecution. The Lord Advocate denied that the Scottish government had any responsibility to act, informing Parliament that a 'public prosecutor was not a minister of police. It was no part of the business of a public prosecutor to hunt out crime.' ${ }^{55}$ The Royal 
British Bank prosecution did not set a precedent of state prosecutions of corporate frauds. The intention was that the new statutory powers against fraud could be used by the victims of fraud when they judged civil actions to be inadequate, which did slowly begin to happen from the 1860 s. ${ }^{56}$

But judges were not impressed with the new statutory provisions against fraud, and interpreted them narrowly, continuing to base their judgements on principles derived from common law and equity, which tended to rest on notions of caveat emptor ${ }^{57}$ So, the fact that the prospectus launching Overend and Gurney on the stock market in 1865, shortly before its collapse the following year, had concealed the huge debts the private firm had accumulated, was not a sound basis for a criminal prosecution, according to Chief Justice Alexander Cockburn. Entirely false representations rendered a person liable in contractual disputes, explained Cockburn, but rather than making false representations, the prospectus in fact said nothing at all about the firm's assets. ${ }^{58}$ Certainly, it failed to mention the existence of a second deed transferring the private firm's debts to the company, but it was an accepted principle in equity that non-disclosure was not fraud. ${ }^{59}$ This reading of the law was based on a view of shareholders as responsible and active citizens who were well able to look after their own interests and who should not rely on an overly protective criminal law. While convictions began to be secured in cases of misappropriation of company money, judges and juries tended not to see misrepresentation in such a serious light. ${ }^{60}$ Further shifts in attitude were required for this situation to change, which is what began to occur in the final third of the century.

\section{Enforcing the law}


The intervention of the criminal law was not felt to be particularly urgent when society still had faith in the ability of extra-legal sanctions to regulate the market. Criminal prosecutions could almost be framed as superfluous due to the reputational damage and public humiliation suffered by those associated with fraud. ${ }^{61}$ But by the 1870 s, reputation as a regulatory instrument seemed no longer to be working. Dishonesty was supposed to be the route to disgrace, but the connection between the two was becoming attenuated. The idea was perfectly encapsulated in Antony Trollope's novel The Way We Live Now, serialised between 1874 and 1875. The story of the rise and fall of corrupt financier Augustus Melmotte, the novel shows how cash-strapped aristocrats embrace rather than shun the businessman, thinking that he can make them rich. Trollope later commented that he was driven to write by the belief that in modern London 'a certain class of dishonesty, dishonesty magnificent in its proportions, and climbing into high places, has become at the same time so rampant and so splendid that there seems to be reason for fearing that men and women will be taught to feel that dishonesty, if it can become splendid, will cease to be abominable. ${ }^{92}$ That Trollope's novel articulated a wider sentiment is clear when one reads the 1870 s press, which is full of reflections which could have been taken straight from the novel's pages. In 1875, The Times saw 'increasing audacity, increasing greed, increasing fraud, increasing impunity ... what we are noticing is notorious and universal. There are scores of persons now going about with hardly a blemish on their characters, and revelling in the profits of this traffic. ${ }^{93}$ The implication was clear - if the market was no longer able to expel its corrupt elements through the stigmatisation of dishonest behaviour, then the external intervention of the law was needed to clean it up. ${ }^{64}$

Another contributory factor was changing attitudes to investors. Traditionally viewed as authors of their own misfortunes, new attitudes began to prevail. The idea of passive rentier investment, anathema in the earlier part of the century, was gaining acceptance, aided 
by the concession of limited liability from $1855 .{ }^{65}$ This 'depoliticisation' of the shareholder was also cause and consequence of changing standards of corporate governance, which even before mid-century was moving away from the idea that companies were participatory 'republics'. ${ }^{66}$ Shareholders had fewer powers, and consequently less of a responsibility to hold their executives to account. When things went wrong, it was not necessarily their fault. 'To trust, as at present, to the public to protect themselves is to lean upon a broken reed', argued The Standard in $1878 .{ }^{67}$ This view only became more pronounced with the growing diversification of the shareholder base, facilitated by falling share denominations, and encouraged, particularly from the 1880 s, by a vibrant popular financial press. ${ }^{68}$

For so long seen as a private matter to be resolved between the individuals concerned, fraud was reconfigured as a public offence. Companies, and the large capitals they mobilised, once regarded as an unstable and unnatural element of the economy, were coming to be understood as vital to the nation's economic wellbeing. ${ }^{69}$ Financial crime shook confidence in the developing market for company shares, and anything which threatened the flow of speculative investment was to be discouraged by the law. ${ }^{70}$ As one newspaper put it in 1877 : 'Every sovereign buttoned up in the pocket instead of being invested, is a loss not only to the individual but to the productive power of capital; yet wide spread nefariousness in handling investments would lead to an extensive buttoning up of pockets, and the consequent stagnation of the tributaries which flow into the aggregate ocean of wealth. ${ }^{71}$ Letting frauds go unpunished would cause such a stagnation by sowing mistrust through the economy. And as the number of companies grew - there were over 13,000 registered companies by 1890 - it became difficult to argue that their shareholders were the only, or even the principal, victims. ${ }^{72}$ Large corporate failures affected customers, creditors, and employees as well as shareholders, and their wider effects were harder to ignore. ${ }^{73}$ 
As public offences, it began to seem inappropriate to leave their prosecution, and the substantial costs involved, to the victims. ${ }^{74} \mathrm{~A}$ host of other problems with private prosecution were identified. First, relying on private initiative reduced the chances of a prosecution taking place at all for, as Master of the Rolls Sir George Jessel put it, 'what is everybody's business is nobody's business' ${ }^{75}$ Second, if they were initiated, the limited resources or poor judgement of the prosecutors meant that they might be ineptly conducted: the private prosecution of Overend and Gurney, for example, was not aided by the prosecutors' chosen barrister, the eccentric radical and mystic, Edward Kenealy. ${ }^{76}$ Third, the economic interests of the prosecutors could undermine higher notions of justice. Prosecutions could be 'compromised' - that is, abandoned if the prosecutors were bought off by the defendants, or could be malicious in intent, designed to coerce their subjects into making a financial settlement regardless of the rights or wrongs of the case. Sometimes such motives were quite openly admitted, as in the prosecution of the directors of the Peat Coal Company in 1874, abruptly abandoned as soon as the defendants agreed to terms in a Chancery suit, much to the annoyance of the presiding magistrate. ${ }^{77}$

The solution to the faulty private prosecution was nationalisation. ${ }^{78}$ Initially, this was effected on an ad hoc basis by means of Treasury prosecutions - under Benjamin Disraeli's Conservative government (1874-80) the Treasury Solicitor successfully prosecuted in the cases of the Co-Operative Credit Bank (1876), the Artisans, Labourers, and General Dwellings Company (1877), and the Albion Life Assurance Society (1878) ${ }^{79}$ In each case, the Home Secretary instructed the Treasury Solicitor to act, but a more formal mechanism was put in place by the Prosecution of Offences Act of 1879, inspired to some degree by the example of the swift and successful prosecution of the management of the City of Glasgow Bank by the Lord Advocate following the bank's collapse in October $1878 .^{80}$ The act established a Director of Public Prosecutions (DPP) for England and Wales. ${ }^{81}$ 
Thus, by 1880 there was a statute criminalising misappropriation and misrepresentation, and a public official tasked with prosecuting frauds. But significant barriers to the effective punishment of fraud remained. For one thing, the new office was not generously resourced, with the DPP given just one assistant and three clerks. ${ }^{82}$ Moreover, the DPP's role was envisaged as limited: to supplement, rather than supplant, private prosecution. Rules drawn up in 1880 stipulated that the DPP would only prosecute in cases which he deemed to be 'of importance or difficulty, or in which special circumstances seem to him to render his action necessary to secure the due prosecution of an offender' ${ }^{83}$

Deciding which cases to take on and which to reject placed an enormous burden on the DPP and his small team. Prosecuting a case which did not lead to a conviction, or refusing to act in a case which was considered scandalous, left the DPP open to excoriation by the press. But enduring judicial conservatism, with the principle of caveat emptor still framing many judges' approaches to fraud cases, meant that the DPP tended only to act in cases of 'lowhanging fruit', declining to take on cases in which the chances of success were not high. ${ }^{84}$ Indeed, his failure to prosecute in a case involving the defrauding of a young ballet dancer created such a scandal that his office was reorganised, being absorbed into the department of the Treasury Solicitor, who took on both roles. ${ }^{85}$

These final obstacles were overcome in the 1890s. Pivotal was an administrative reform of 1890. Following a Board of Trade report on company liquidations carried out in Chancery since 1862 which revealed a deeply unsatisfactory state of affairs - over 40 per cent of companies were in liquidation for over five years, and the costs of the system were enormous - Parliament passed a Winding-Up Act in 1890 designed to improve procedures. ${ }^{86}$ This act had the twin aims of making liquidation speedier and less expensive (which appealed to business) and securing greater publicity in the winding-up process in order to discourage fraud, in the interests of the wider community. Publicity was to be secured by the 
appointment of an Official Receiver in Bankruptcy who would co-ordinate liquidation and establish the causes of failure, reporting to the court whether fraud had been committed. The Official Receiver would also report to a new Board of Trade official, the Inspector-General in Companies Liquidation, who would oversee the administration of the act, and make annual reports to Parliament. ${ }^{87}$ The overall aim was to bring companies in line with the more rigorous system which regulated the bankruptcies of individuals. ${ }^{88}$

Although the act did not directly deal with the issue of criminal sanctions, the way it was implemented by the Board of Trade transformed the way in which decisions on prosecutions were made. The extent of fraud uncovered in the Court of Bankruptcy during 1891, the first year of the act's operation, shocked the Board to such an extent that it collaborated with the DPP to establish a system whereby the Board would bring cases requiring prosecution to him, so that they could be conducted at the public expense. ${ }^{89}$ This was a crucial change: it took away responsibility for initial investigation from the DPP, who could now prosecute cases secure in the knowledge that they had been thoroughly sifted and judged worthy of official action.

The result was a far greater volume of state prosecutions, as many as half a dozen in some years, significantly outnumbering private prosecutions. And these cases came before a new generation of judges who proved willing to follow the recent trend in civil litigation which placed more responsibility on sellers not to mislead contracting parties. ${ }^{90}$ These judges interpreted the legislation against fraud expansively, with the result that a wider range of offences were now defined as criminal. Shareholders' property was given greater protection by judgements which criminalised the payment of secret commissions to board members, while moving money between companies at audit time in order to conceal losses also began to be successfully prosecuted. False prospectuses now came under the purview of the criminal law, while fraudulent companies which did not issue prospectuses were also 
successfully prosecuted. 'Honest' intentions when issuing a false balance sheet were no longer the effective defence they once were: as one prosecuting barrister said: 'It would be a very bad day for the commercial morality of this country when only a man who intended to enrich himself personally could be charged with fraud. ${ }^{91}$ And the activities of outside brokers, whose 'bucket shops' had initially operated with impunity, were also successfully targeted for the first time. ${ }^{92}$

\section{Conclusion}

This article has argued that rather than regarding Victorian society as essentially comfortable with fraud as the price that had to be paid for a growth-focused and risk-taking economy, it is more accurate to view this as a society preoccupied with the problem of fraud, and which eventually turned to the criminal law as the best method of tackling the issue. Admittedly, it is very clear that criminal sanctions in no way solved the problem of company fraud, and the state did not prosecute every case of alleged fraud, a fact which could generate much controversy, as in the case of Whitaker Wright, managing director of the London and Globe Finance Corporation, in 1903. ${ }^{93}$ Nevertheless, criminalisation did raise the standards expected of company executives: in particular, making misrepresentation in company accounts and prospectuses a criminal offence meant that telling the truth was, at least in theory, now a legal requirement for directors. Moreover, the state took on responsibility for enforcing these standards. Together, this represented a very different approach from that taken in the first half of the century.

These criminal prosecutions performed a wide variety of useful functions. There were clear social benefits. Radical critiques of society had been based on the belief that there was one law for the rich and one for the poor, that class bias was embedded in the statute book 
and in the legal structures of the nation. ${ }^{94}$ While in many ways British society remained profoundly undemocratic, in the final decades of the century it became harder to overlook the construction of a disciplinary system of criminal law targeted at company management and enforced through a growing bureaucracy. Of course, proletarian wrongdoers continued to make up the vast majority of prison populations, but as the number of prosecutions of company directors and managers grew, the radical critique began to be undercut. The trials which followed joint-stock frauds, often lengthy and highly-publicised, dramatised the fairness of society, with the public seeing rich rogues punished as well as poor ones. When Jabez Balfour, a building society tycoon, was convicted of fraud in 1895, the judge stressed that it was 'the duty of those who administer the law to prove that the man of position who transgresses it must undergo the same punishment as a common thief'; as a result he sentenced Balfour to fourteen years' penal servitude. ${ }^{95}$ It is not unreasonable to suppose that outcomes like this helped to rebuild a degree of popular trust in society.

Economically speaking, there were also clear benefits. Criminal prosecutions helped to restore confidence in times of crisis. For example, the exposure of egregious misrepresentations in the balance sheets of the City of Glasgow Bank in 1878 was shocking, and spread mistrust through the banking sector north and south of the border. But the government's swiftness in ordering the arrest of the bank's management did much to 'calm public excitement', restoring confidence by assuring investors that similar practices could not be pursued elsewhere with impunity. ${ }^{96}$

Moreover, criminal prosecutions helped to legitimise Britain's permissive company law which many believed underpinned economic growth. Bad cases of fraud increased popular demands for regulatory interventions such as placing controls on company formation, restricting access to corporate privileges like limited liability, and monitoring company behaviour through measures such as government audit of accounts. ${ }^{97}$ Criminal prosecutions 
represented an effective alternative to these restraints to trade. This dynamic can be seen in the debates surrounding the concession of general limited liability in the mid-1850s. Opponents of the legislation claimed that it would encourage fraud, but the Board of Trade saw things differently, arguing that 'it was the duty of the Legislature to prevent fraud, not by prohibiting a class of transactions, many of which were honest and advantageous to the public and the parties concerned, but by taking care that fraud, wherever it existed, should be detected and punished. ${ }^{98}$ The model thus adopted seemed to many to be the best of both worlds: entrepreneurial freedom was safeguarded, but punishment awaited those who abused this freedom. So, there was a symbiotic rather than a contradictory relationship between freedom of contract and an active and robust criminal law. In paying disproportionate attention to permissive company law, and neglecting the stiffening criminal law, historians have given a misleading impression of the Victorian approach to the regulation of business.

The Victorian approach has lessons for today. In his 2012 Reith Lectures, Niall Ferguson addressed the question of how governments should respond to the global economic crisis of 2008. He castigated those whose solution to economic breakdown is greater regulation: in his view, complex regulation actually contributes to crises. Yet this was no simple call for laissez faire. Instead he argued that deregulation should be accompanied by stiffer and surer penalties for fraud, noting that 'greedy people will only commit fraud or negligence if they feel that their misdemeanour is unlikely to be noticed or severely punished'. Opposing stricter regulation whilst supporting 'the exemplary incarceration of bad bankers ... are not contradictory but complementary' positions, he concluded. ${ }^{99}$

The absence of criminal trials following the 2008 crisis - at least in the UK and the US - has attracted much comment. ${ }^{100}$ Certainly this inaction suggests that in the recent past a whole host of new obstacles have developed discouraging the criminal prosecution of corporate fraud, including the unhealthy closeness between governments and the financial 
sector, the complexity of the modern financial system which makes proving knowledge and intent difficult, and the fear that 'showcase trials of corporate executives would undermine the already deteriorating public trust in the way capitalism was functioning'. ${ }^{101}$ There have lately been glimmers of a tougher line - the Financial Services (Banking Reform) Act of 2013, which targets senior managers whose actions caused the failure of a financial institution, ${ }^{102}$ and the Serious Fraud Office's successful prosecution of Barclays traders for LIBOR manipulations in $2016 .{ }^{103}$ Yet the continuing under-funding of the SFO suggests a lack of political will to seriously tackle white-collar crime,${ }^{104}$ and it remains doubtful whether governments genuinely understand the benefits of bringing the criminal law into boardrooms, with serious repercussions for Britain's society and its economy.

\section{Bibliography}

Arnold, A. J., and Sean McCartney. George Hudson: The Rise and Fall of the Railway King. London: Hambledon, 2004.

Atiyah, Patrick S. The Rise and Fall of Freedom of Contract. Oxford: Clarendon Press, 1979.

Balleisen, Edward J. Fraud: An American History from Barnum to Madoff. Princeton:

Princeton University Press, 2017.

Box, Steven. Power, Crime, and Mystification. London: Tavistock Publications, 1983.

Campbell, Gareth and Turner, John D. "Dispelling the Myth of the Naïve Investor during the British Railway Mania, 1845-1846.” Business History Review 86 (2012): 3-41.

Cullen, Francis T., Jeniffer Hartman, and Cheryl Lero Johnson. "Bad Guys: Why the Public Supports Punishing White-Collar Offenders." Crime, Law and Social Change 51 (2009): 3144. 
Elliott, Geoffrey. The Mystery of Overend and Gurney: A Financial Scandal in Victorian London. London: Methuen, 2006.

Emsley, Clive. Crime and Society in England, 1750-1900. 2nd ed. Harlow: Longman, 1996. Faller, Lincoln B. Turned to Account: The Forms and Functions of Criminal Biography in Late Seventeenth- and Early Eighteenth-Century England. Cambridge: Cambridge University Press, 1987.

Ferguson, Niall. “The Darwinian Economy.” 26 June 2012:

http://www.bbc.co.uk/programmes/articles/3XhZsLTM18KBQX6C97w8K6z/niall-ferguson-thedarwinian-economy.

Fisher, Jonathan, Claire Cregan, James Di Guilio, and Jodi Schutze. "Economic Crime and the Global Financial Crisis.” Law and Financial Markets Review 4 (2011): 276-89.

Freeman, Mark, Robin Pearson, and James Taylor. Shareholder Democracies? Corporate Governance in Britain and Ireland before 1850. Chicago: Chicago University Press, 2012.

Gatrell, Vic A. C. "Crime, Authority and the Policeman-State.” In The Cambridge Social History of Britain, 1750-1950, Vol. III, edited by Francis M. L. Thompson, 243-310.

Cambridge: Cambridge University Press, 1990.

Gatrell, Vic A. C. The Hanging Tree: Execution and the English People, 1770-1868. Oxford: Oxford University Press, 1996.

Godfrey, Barry. "Changing Prosecution Practices and their Impact on Crime Figures, 18571940.” British Journal of Criminology 48, no. 2 (2008): 171-89.

Godfrey, Barry S., and John P. Locker. "The Nineteenth-Century Decline of Custom, and its Impact on Theories of 'Workplace Theft' and 'White Collar Crime'.” Northern History 38, no. 2 (2001): 261-73.

Handler, Phil. "Forgery and the End of the 'Bloody Code' in Early Nineteenth-Century England." Historical Journal 48, no. 3 (2005): 683-702. 
Harling, Philip. The Waning of 'Old Corruption': The Politics of Economical Reform in Britain, 1779-1846. Oxford: Oxford University Press, 1996.

Hay, Douglas, Peter Linebaugh, John G. Rule, Edward P. Thompson, and Cal Winslow. Albion's Fatal Tree: Crime and Society in Eighteenth-Century England. London: Allen Lane, 1976.

Hilton, Boyd. The Age of Atonement: The Influence of Evangelicalism on Social and Economic Thought, 1785-1865. Oxford: Clarendon Press, 2001.

Hollow, Matthew. Rogue Banking: A History of Financial Fraud in Interwar Britain. Basingstoke: Palgrave Macmillan, 2015.

Itzkowitz, David C. "Fair Enterprise or Extravagant Speculation: Investment, Speculation, and Gambling in Victorian England." Victorian Studies 45, no. 1 (2002): 121-47.

Jefferys, James B. “The Denomination and Character of Shares, 1855-1885.” Economic

History Review 16, no. 1 (1946): 45-55.

Jewkes, Yvonne. Media and Crime. London: Sage, 2011.

Johnson, Paul. "Civilizing Mammon: Laws, Morals and the City in Nineteenth-Century England." In Civil Histories: Essays Presented to Sir Keith Thomas, edited by Peter Burke, Brian Harrison, and Paul Slack, 301-19. Oxford: Oxford University Press, 2000.

Johnson, Paul. Making the Market: Victorian Origins of Corporate Capitalism. Cambridge: Cambridge University Press, 2010.

Johnstone, Paul. "Serious White Collar Fraud: Historical and Contemporary Perspectives." Crime, Law \& Social Change 30, no. 2 (1999): 107-30.

Kahan, Dan M., and Eric A. Posner. "Shaming White-Collar Criminals: A Proposal for Reform of the Federal Sentencing Guidelines.” Journal of Law \& Economics, 42, no. 1 (1999): 365-92. 
Kindleberger, Charles P. Manias, Panics and Crashes: A History of Financial Crises. $4^{\text {th }}$ ed. Basingstoke: Palgrave, 2002.

Kostal, Rande W. Law and English Railway Capitalism, 1825-1875. Oxford: Oxford University Press, 1997.

Lee, Alan J. The Origins of the Popular Press in England, 1855-1914. London: Croom Helm, 1976.

Levi, Michael. "The Media Construction of Financial White-Collar Crimes." British Journal of Criminology 46 (2006): 1037-57.

Levi, Michael. Regulating Fraud: White-Collar Crime and the Criminal Process. London: Tavistock Publications, 1987.

'LIBOR Traders and Submitters Found Guilty', SFO Website, 4 July 2016:

https://www.sfo.gov.uk/2016/07/04/libor-traders-submitters-found-guilty/

Life of John, Lord Campbell, 2 Vols., edited by Mary Scarlett Hardcastle. London: John Murray, 1881.

Lobban, Michael. "Nineteenth Century Frauds in Company Formation: Derry v. Peek in Context." Law Quarterly Review 112 (1996): 287-334.

Locker, John P. “The Paradox of the 'Respectable Offender': Responding to the Problem of White-Collar Crime in Victorian and Edwardian England.” In Punishment and Control in Historical Perspective, edited by Helen Johnston, 115-134. Houndmills: Palgrave Macmillan, 2008.

Locker, John P. “'Quiet Thieves, Quiet Punishment': Private Responses to the 'Respectable' Offender, c. 1850-1930." Crime, Histoire et Societes 9, no. 1 (2005): 9-31.

McGowen, Randall. “The Bank of England and the Policing of Forgery 1797-1821.” Past \& Present 186 (2005): 81-116. 
McGowen, Randall. "The Fauntleroy Forgeries and the Making of White-Collar Crime.” In Legitimacy and Illegitimacy in Nineteenth-Century Law, Literature and History, edited by Margot C. Finn, Michael Lobban, and Jenny Bourne Taylor, 93-118. Houndmills: Palgrave Macmillan, 2010.

McGowen, Randall. "From Pillory to Gallows: The Punishment of Forgery in the Age of the Financial Revolution.” Past \& Present 165 (1999): 107-40.

McQueen, Rob. A Social History of Company Law: Great Britain and the Australian Colonies, 1854-1920. Farnham: Ashgate, 2009.

Moss, David J. "Business and Banking: Ethics and White-Collar Crime in Norwich, 18251831." Albion 29, no. 3 (1997): 373-98.

Newton, Lucy A., and Victoria Barnes. "Virtuous Banking: The Role of the Community in Monitoring Joint-Stock Banks and their Managements in the Nineteenth Century." in The Challenges of Capitalism for Virtue Ethics and the Common Good: Interdisciplinary Perspectives, edited by Kleio Akrivou and Alejo Jose G. Sison, 62-74. Cheltenham: Edward Elgar, 2016.

Odlyzko, Andrew. "The Collapse of the Railway Mania, the Development of Capital Markets, and the Forgotten Role of Robert Lucas Nash.” Accounting History Review 21, no. 3 (2011), 309-45.

Paul, Helen J. The South Sea Bubble: An Economic History of its Origins and Consequences. Abingdon: Routledge, 2011.

Perez-Truglia, Ricardo, and Ugo Troiano. "Shaming Tax Delinquents: Theory and Evidence from a Field Experiment in the United States.” NBER Working Paper, 21264, June 2015. Pontell, Henry N., William Black, and Gilbert Geis. “Too Big to Fail, Too Powerful to Jail? On the Absence of Criminal Prosecutions after the 2008 Financial Meltdown." Crime, Law and Social Change 61, no. 1 (2014): 1-13. 
Pontell, Henry N., and Gilbert Geis. "The Trajectory of White-Collar Crime Following the Great Economic Meltdown.” Journal of Contemporary Criminal Justice 30, no. 1 (2014): 7082.

Porter, Dilwyn. "City Editors and the Modern Investing Public: Establishing the Integrity of the New Financial Journalism in Late Nineteenth-Century London.” Media History 4, no. 1 (1998): 49-60.

Report of the Trial of the Directors of the City of Glasgow Bank. Edinburgh: Edinburgh Publishing Company, 1879.

Robb, George. White-Collar Crime in Modern England: Financial Fraud and Business Morality, 1845-1929. Cambridge: Cambridge University Press, 1992.

Ross, Duncan. "Savings Bank Depositors in a Crisis: Glasgow 1847 and 1857.” Financial History Review 20, no. 2 (2013): 183-208.

Ryder, Nicholas. “'Greed, for Lack of a Better Word, is Good. Greed is Right. Greed Works': A Contemporary and Comparative Review of the Relationship between the Global Financial Crisis, Financial Crime and White Collar Criminals in the U.S. and the U.K." British Journal of White Collar Crime 1, no. 1 (2016): 3-47.

Shannon, H. A. “The Limited Companies of 1866-1883.” Economic History Review 4, no. 3 (1933): 290-316.

Sindall, Rob. "Middle-Class Crime in Nineteenth-Century England." Criminal Justice History 4 (1983): 23-40.

Slapper, Gary and Steve Tombs. Corporate Crime. Harlow: Longman, 1999.

Styles, John. "Embezzlement, Industry, and the Law in England, 1500-1800." In Manufacture in Town and Country before the Factory, edited by Maxine Berg, Pat Hudson and Michael Sonenscher, 173-210. Cambridge: Cambridge University Press, 1983. 
Sunderland, David. Social Capital, Trust and the Industrial Revolution, 1780-1880. London: Routledge, 2007.

Sutherland, Edwin H. White Collar Crime: The Uncut Version. New Haven: Yale University Press, 1983.

Sutherland, Edwin H. "White-Collar Criminality." American Sociological Review 5 (1940): $1-12$.

Taylor, James. Boardroom Scandal: The Criminalization of Company Fraud in NineteenthCentury Britain. Oxford: Oxford University Press, 2013.

Taylor, James. "Commercial Fraud and Public Men in Victorian Britain.” Historical Research 78 (2005): 230-52.

Taylor, James. "Company Fraud in Victorian Britain: The Royal British Bank Scandal of 1856." English Historical Review 122 (2007): 700-24.

Taylor, James. Creating Capitalism: Joint-Stock Enterprise in British Politics and Culture, 1800-1870. Woodbridge: Boydell and Brewer, 2006.

Taylor, James. "Privacy, Publicity, and Reputation: How the Press Regulated the Market in Nineteenth-Century England.”Business History Review 87, no. 4 (2013): 679-701.

Thompson, Edward P. Whigs and Hunters: The Origin of the Black Act. London: Allen Lane, 1975.

Trollope, Anthony. An Autobiography. Oxford: Oxford University Press, 1980.

Wilson, Sarah. "In Defence of Respectability: Financial Crime, the 'High Art' Criminal and the Language of the Courtroom, 1850-1880." In The Golden Age: Essays in British Social and Economic History, 1850-1870, edited by Ian Inkster, Colin Griffith, Jeff Hill and Judith Rowbotham, 199-215. Aldershot: Ashgate, 2000.

Wilson, Sarah. "Law, Morality and Regulation: Victorian Experiences of Financial Crime." British Journal of Criminology 46 (2006): 1073-90. 
Wilson, Sarah. The Origins of Modern Financial Crime: Historical Foundations and Current Problems in Britain. London: Routledge, 2014.

${ }^{1}$ Sutherland, "White-Collar Criminality." The paper was delivered at the annual meeting of the American Sociological Society in December 1939.

${ }^{2}$ Thompson, Whigs and Hunters; Hay et al., Albion's Fatal Tree; Gatrell, The Hanging Tree. An early exception was Sindall, "Middle-Class Crime."

${ }^{3}$ Robb, White-Collar Crime.

${ }^{4}$ McGowen, "From Pillory to Gallows"; McGowen, "Bank of England”; McGowen, "The Fauntleroy Forgeries"; Handler, "Forgery and the End of the 'Bloody Code"”; Godfrey and Locker, "Nineteenth-Century Decline of Custom”; Locker, “'Quiet Thieves, Quiet Punishment"”; Locker, "Paradox of the 'Respectable Offender."

${ }^{5}$ Sindall, "Middle-Class Crime," 32, 38; Gatrell, "Crime, Authority and the PolicemanState," 270-1; Robb, White-Collar Crime, 10, 158; Johnstone, "Serious White Collar Fraud," 110-11; Johnson, “Civilizing Mammon,” 319.

${ }^{6}$ Wilson, "In Defence of Respectability," 206.

${ }^{7}$ Taylor, “Commercial Fraud and Public Men”; Wilson, "Law, Morality and Regulation"; Taylor, "Company Fraud in Victorian Britain."

${ }^{8}$ Taylor, Boardroom Scandal; Wilson, Origins of Modern Financial Crime. For a US perspective, see Balleisen, Fraud: An American History.

${ }^{9}$ Pontell et al, "Too Big to Fail”; Cullen et al, "Bad Guys"; Kahan and Posner, "Shaming White-Collar Criminals"; Perez-Truglia and Troiano, "Shaming Tax Delinquents." ${ }^{10}$ The notion of the 'Bloody Code' was the creation of reformers in the early nineteenth century who portrayed this mass of penal statutes as the product of a less enlightened age: see Handler, "Forgery and the End of the 'Bloody Code."” 
1130 Geo. 2 c. 24 , s. 1.

1239 Geo. 3, c. 85, s. 1; Styles, "Embezzlement, Industry, and the Law"; Godfrey and

Locker, "Decline of Custom,” 268-9.

${ }^{13}$ Faller, Turned to Account, 192.

${ }^{14}$ For a recent treatment of the episode, see Paul, South Sea Bubble.

${ }^{15}$ For more, see Taylor, Boardroom Scandal, 151, 163.

${ }^{16}$ Secret Committee on Joint Stock Banks, PP 1837 XIV.155, 92, 155. See also Moss,

"Business and Banking."

${ }^{17}$ Freeman et al, Shareholder Democracies.

${ }^{18}$ For more on limited liability, see Johnson, Making the Market, ch. 5.

${ }^{19}$ For more on the timing of these, see Kindleberger, Manias, Panics and Crashes, ch. 3.

${ }^{20}$ Hansard, 3s, 197: 975-95 (1 July 1869).

${ }^{21}$ Campbell and Turner, "Dispelling the Myth."

${ }^{22}$ Lloyd's Weekly Newspaper, 29 July 1849.

${ }^{23}$ The boundaries between speculation, investment, and gambling were contested and shifted over time: Itzkowitz, "Fair Enterprise.”

${ }^{24}$ Morning Chronicle, 27 April 1848.

${ }^{25}$ The severest sentence handed out was 14 years' transportation for the actuary of the Tralee Savings Bank, who admitted embezzling £20,000: Reg. v. Lynch (1848), Freeman's Journal, 26 July 1848. For more on savings banks and crisis, see Ross, "Savings Bank Depositors."

26 Taylor, "Privacy, Publicity, and Reputation," 685-8.

${ }^{27}$ Morning Chronicle, 9 December 1825.

${ }^{28}$ Taylor, Boardroom Scandal, 39-42.

${ }^{29}$ Sunderland, Social Capital. For an example of community monitoring in joint-stock banks, see Newton and Barnes, "Virtuous Banking." 
${ }^{30}$ Wilson, Origins of Modern Financial Crime, 128-36.

${ }^{31}$ Godfrey, "Changing Prosecution Practices."

${ }^{32}$ Taylor, Boardroom Scandal, 179.

${ }^{33}$ Harling, Waning of 'Old Corruption.'

${ }^{34}$ Kostal, Law and English Railway Capitalism; Lobban, "Nineteenth Century Frauds."

${ }^{35}$ Sutherland, White Collar Crime, 250-1.

${ }^{36}$ Box, Power, Crime, and Mystification, 16-17; Slapper and Tombs, Corporate Crime, 91-6.

${ }^{37}$ Jewkes, Media and Crime, 23.

${ }^{38}$ Levi, Regulating Fraud, 11; Levi, "Media Construction,” 1052-3.

${ }^{39}$ Levi, Regulating Fraud, 12.

${ }^{40}$ Levi, "Media Construction," 1052.

${ }^{41}$ Lee, Origins of the Popular Press, 86-7.

42 Observer, 20 May 1849.

${ }^{43}$ Arnold and McCartney, George Hudson; Odlyzko, "Collapse of the Railway Mania."

${ }^{44}$ Instead, Hudson faced ruinous civil actions: Arnold and McCartney, George Hudson, 215-

22; Taylor, Boardroom Scandal, 88-9; Wilson, Origins of Modern Financial Crime, 137.

${ }^{45}$ See for example Lloyd's Weekly Newspaper, 21 September 1856; The Times, 24 September 1856.

46 Taylor, "Commercial Fraud and Public Men,” 238.

${ }^{47}$ Observer, 3 May 1857.

${ }^{48}$ Hansard, 3s, 145: 680 (21 May 1857).

${ }^{49}$ Reg. v. Esdaile (1858) 175 ER 696.

${ }^{50}$ Diary entry for 9 May 1858, Life of John, Lord Campbell, 358.

${ }^{51}$ Law Times, 19 June, 10 July 1858, 5 March 1859. 
5220 \& 21 Vict. c. 54; Wilson, Origins of Modern Financial Crime, 140-7; Taylor,

Boardroom Scandal, 111-12.

${ }^{53}$ Emsley, Crime and Society, 277-8.

$547 \& 8$ Geo. IV c. 29 , s. 53.

${ }^{55}$ Hansard, 3s, 149: 1197 (16 April 1858).

${ }^{56}$ Taylor, Boardroom Scandal, ch. 6.

${ }^{57}$ Atiyah, Rise and Fall.

${ }^{58}$ Ibid., 469.

${ }^{59}$ Reg. v. Gurney (1869) 11 Cox 414.

${ }^{60}$ See Cockburn's views in Reg. v. Murch (1880), The Times, 6 May 1880.

${ }^{61}$ Taylor, "Commercial Fraud."

${ }^{62}$ Trollope, An Autobiography, 354-5.

${ }^{63}$ The Times, 11 August 1875.

${ }^{64}$ For more on the relationship between honesty, respectability, and lawfulness, see Wilson, Origins of Modern Financial Crime, ch. 6.

${ }^{65}$ Taylor, Creating Capitalism, ch. 4.

${ }^{66}$ Freeman et al, Shareholder Democracies.

${ }^{67}$ Standard, 10 June 1878.

${ }^{68}$ Shannon, "Limited Companies," 296; Jefferys, "Denomination and Character of Shares."

For the financial press, see Porter, "City Editors and the Modern Investing Public."

${ }^{69}$ Taylor, Creating Capitalism, ch. 1; Hilton, Age of Atonement, ch. 4.

${ }^{70}$ Wilson, Origins of Modern Financial Crime, 132-3.

${ }^{71}$ Huddersfield Daily Chronicle, 29 October 1877.

${ }^{72}$ Returns of the Names, Objects or Business, Places where Business is or was Conducted, Date of Registration, \&c, and the Total Amount of Calls Received of all Joint Stock 
Companies Formed since the 1st day of January 1889 to the 31 st day of December 1889, and also the Number of Shareholders in Each of the said Companies at the Date of the Last Return, PP 1890 LXVIII. 190-2.

${ }^{73}$ For more on criminal trials and the 'public interest', see Wilson, Origins of Modern Financial Crime, 166-72.

${ }^{74}$ It should be noted that the 1862 Companies Act allowed the Court of Chancery to order prosecution paid for out of the assets of the company: 25 \& 26 Vict. c. 89 , ss. 167-8.

${ }^{75}$ Report from the Select Committee on the Companies Acts, 1862 and 1867, PP 1877 VIII. 125.

${ }^{76}$ Elliott, Overend and Gurney, 215-16.

77 The Times, 9, 14 July 1874.

${ }^{78}$ This move was in keeping with the greater willingness of governments in the second half of the century to contemplate state solutions to market failures, following the establishment of the Post Office Savings Bank in 1861 and the nationalisation of the telegraph service in 1868-70.

${ }^{79}$ Taylor, Boardroom Scandal, 169-76.

${ }^{80}$ Report of the Trial of the Directors, 234-55.

8142 \& 43 Vict. c. 22; Taylor, Boardroom Scandal, 183-4.

${ }^{82}$ Taylor, Boardroom Scandal, 191.

${ }^{83}$ Report of the Committee Appointed to Inquire into the Office of Public Prosecutor, PP 1884 XXIII. 38-9.

${ }^{84}$ For more on judicial attitudes to business see Wilson, Origins of Modern Financial Crime, 192-9.

${ }^{85}$ Taylor, Boardroom Scandal, 197-202. 
${ }^{86}$ Return of all Companies which have been Ordered to be Wound up, under the Provisions of the Companies Acts, Compulsorily or under the Supervision of the Court, since the Commencement of the Companies Act, 1862, PP 1888 LXXX.

8753 \& 54 Vict. c. 63.

${ }^{88}$ For more on the relationship between bankruptcy and criminalisation, see Wilson, Origins of Modern Financial Crime, 222-4.

${ }^{89}$ Return Showing the Working of the Regulations made in 1886 for Carrying out the Prosecution of Offences Acts, 1879 and 1884, PP 1892 LXV. 22.

${ }^{90}$ Atiyah, Rise and Fall, 771-2.

${ }^{91}$ Reg. v. Birt (1899), The Times, 23 March 1899.

${ }^{92}$ The cases mentioned in this paragraph are explored in more detail in Taylor, Boardroom Scandal, ch. 9 .

${ }^{93}$ Hansard, 4s, 118: 347-81 (19 February 1903). After Wright was successfully prosecuted privately, the government agreed to pay the costs of the trial: Hansard, 4s, 129: 160-1 (2 February 1904). Fraud continued to be a problem in the twentieth century: Hollow, Rogue Banking.

${ }^{94}$ Harling, Waning of 'Old Corruption.'

95 The Times, 29 November 1895.

${ }^{96}$ Ibid., 22 October 1878.

${ }^{97}$ McQueen, Social History of Company Law, 162-74, 183-92.

${ }^{98}$ Hansard, 3s, 139: 326 (29 June 1855).

${ }^{99}$ Ferguson, "The Darwinian Economy."

${ }^{100}$ Fisher et al., "Economic Crime and the Global Financial Crisis."

${ }^{101}$ Pontell and Geis, "Trajectory of White-Collar Crime," 72.

${ }^{102}$ Financial Services (Banking Reform) Act 2013, c. 33, s. 36. 
103 "LIBOR Traders and Submitters Found Guilty."

${ }^{104}$ Ryder, "“Greed, for Lack of a Better Word, is Good."” 